\section{THANK YOU TO OUR REVIEWERS}

The $B D J$ editorial team would like to thank all the people who help maintain the quality of scientific papers in the $B D J$ by acting as reviewers. The following list contains the reviewers who have worked on scientific papers during 2014.

Thank you also to those who have written a commentary for a research summary and to those who reviewed a manuscript towards the end of this year whose name may not appear below.

\begin{tabular}{|c|c|c|}
\hline Liam Addy & Robert Chate & Keith Horner \\
\hline Sondos Albadri & Ivor Chestnutt & Francis Hughes \\
\hline Salomon Amar & Robert Clark & Sadie Hughes \\
\hline Ana Angelova & Valerie Clerehugh & Nigel Hunt \\
\hline Volponi & Anwen Cope & Richard Ibbetson \\
\hline Jason Armfield & John Cottingham & Marke Ide \\
\hline Paul Ashley & Paul Coulthard & Nicola Innes \\
\hline Nikki Atack & David Craig & Taichi Inui \\
\hline Philip Atkin & StJohn Crean & Robert Ireland \\
\hline Jeremy Bagg & Francesco D'Aiuto & Tony Ireland \\
\hline Leif Bakland & Len D'Cruz & Daryll Jagger \\
\hline Avijit Banerjee & Arthif Daniel & Rob Jagger \\
\hline Steward Barclay & Ulpee Darbar & Ama Johal \\
\hline David Bartlett & Brian Davies & Anthony Johnson \\
\hline Mark Bartold & Stephen Davies & Ilona Johnson \\
\hline Paul Batchelor & Andrew Dawood & Chris Johnston \\
\hline Claire Bates & Basim Dawoud & Ashbjorn Jokstad \\
\hline David Bearn & Maria Devine & Shohei Kasugai \\
\hline Raman Bedi & Stephen Dunne & Elizabeth Kay \\
\hline Philip Benson & Justin Durham & Eero Kerosuo \\
\hline Habib Benzian & Thomas Dyer & Nabiha Khan \\
\hline Werner Bischof & Pamela Ellis & Binish Khatoon \\
\hline Malcolm Bishop & Timothy Elmer & Shinji Kuroda \\
\hline Tore Bjørnland & Jane Evans & TaeHyun Kwon \\
\hline Igor Blum & Jonathan Farmer & Leslie Laing \\
\hline Elizabeth Bower & Roger Forshaw & Thomas Lamont \\
\hline Henk Brand & Ruth Freeman & David Landes \\
\hline Peter Brennan & Jennifer Gallagher & Liran Levin \\
\hline David Brettle & Stanley Gelbier & Ronnie Levine \\
\hline Janine Brooks & Alan Gluskin & Debbie Lewis \\
\hline Paul Brunton & Jenny Godson & Michael Lewis \\
\hline Alison Bullock & Robin Gray & Jonathan Lewney \\
\hline Trevor Burke & Ruth Gray & Gerard Linden \\
\hline Michael Busby & Philip Greene & Singithi Liyanage \\
\hline Elena Calciolari & Miriam Grushka & Chris Louca \\
\hline Julian Caplan & Jennifer Harris & Friederike Luther \\
\hline Fiona Carmichael & Peter Heasman & Christopher Lynch \\
\hline Andrew Carr & Anne Hegarty & Ståle Lyngstadaas \\
\hline Mike Cattell & Ellie Heidari & Louis Mackenzie \\
\hline Graham Chadwick & Rebecca Hierons & Lorna Mann \\
\hline Wyman Chan & Ross Hobson & Zoe Marshman \\
\hline lain Chapple & Alexander Holden & Louis McArdle \\
\hline Philippe Charlier & Colin Hopper & Shane McCrea \\
\hline
\end{tabular}

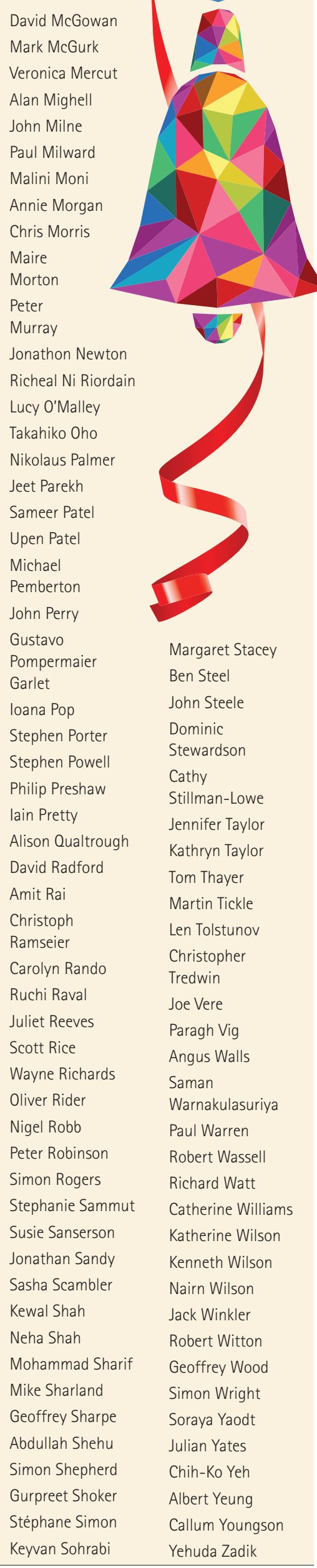
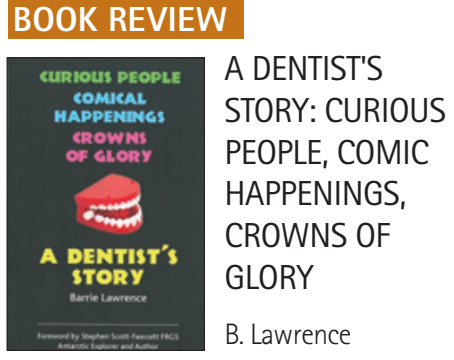

Grosvenor House Publishing Limited

price £8.99; pp 162

ISBN 9781781486986

After reading a plethora of dental texts I was pleasantly surprised to find this autobiographical publication a refreshing delight. The author succeeds in maintaining interest by careful selection of anecdotes combined with a light-hearted tone and appropriate pace.

I particularly enjoyed the vivid recollections from Dr Lawrence's university days. Being a recent graduate myself it was rather interesting to draw comparisons (and certain similarities!) between our undergraduate experiences. It also gave me a greater appreciation of how significantly dentistry and dental practices have evolved over the years: '...it was not uncommon for a family of five or six people to share just one toothbrush' (!).

Although the dental aspect forms an integral part of the content, the author places equal emphasis on his personal development and encounters. The candid nature of the tone gives a very warm, heartfelt touch. It is apparent that the author has made a conscious effort not to overwhelm a reader not very well acquainted with dentistry; although I do question whether the theme would appeal to that audience in the first instance.

It is definitely an inspiring read following Dr Lawrence through his enormously successful professional career, as well as his commitment to spiritual interests. I would recommend this book to anybody in the profession looking for something uncomplicated and entertaining regardless of the stage they are at in their career.

T. DOSHI 